\title{
Pay Sructures and Continuance Commitment in the Manufacturing Companies in Nigeria
}

\author{
G.I. Umoh, Ph.D, MAMN, E. Amah, Ph.D, MNIM, H. I. Wokocha Ph. D, \\ MNIM \\ ( Associate Professor, Department of Management, University of Port Harcourt) \\ (Senior Lecturer, Department of Management, University of Port Harcourt) \\ Chief Lecturer, Department of Office Technology and Management, School of Management, Rivers State \\ College of Arts and Science, Rumuola, Port Harcourt)
}

\begin{abstract}
The study examined the effect of Pay Structures on Continuance Commitment in the Nigerian manufacturing industry. A total of 357 employees were randomly drawn from a population of 3386 employees of the 31 manufacturing companies in Nigeria. The instruments used for data collection were questionnaire and oral interview. A total of 210 copies of the questionnaire were retrieved and analyzed. Spearman's Rank Correlation Statistical tool was used to test the hypotheses. The findings revealed that Pay Structures is significantly related to economic exchange and few alternatives. Based on these findings we concluded that Pay Structures has significant influence on Continuance Commitment. The study therefore recommends that management should utilize the rewards management programme which structures the base pay and compensation package, to attract and retain the right people to the organization.

Key Words: Pay Structures, Continuance Commitment, Economic exchange, Reward management.
\end{abstract}

\section{Introduction}

The objective of the organization is not only to acquire but to maintain an efficient and effective work force and most importantly incite commitment to the organization. This is because commitment is the psychological tie between the organization and the employee, which increase the chance that the employee will remain with the organization and contribute above average effort to the organization (Allen Meyer, 1996). Highly committed employees are less likely to leave the organization to explore other opportunities. Committed organizational members contribute positively to the organization. Cohen (1993) states that "organizations whose members have higher levels of commitment show higher performance and productivity and lower levels of absenteeism and tardiness". This implies that employees with a high level of commitment tend to take greater efforts to perform and invest their resources in the organization (Saal \& Knight, 1987).

People who are committed are less likely to quit and accept other jobs. Thus, the costs of high turnover are not incurred. In addition, committed and highly skilled employees require less supervision. Close supervision and a rigid monitoring control process are time-consuming and costly. Furthermore, a committed employee perceives the value and importance of integrating individual and organizational goals. The employee thinks of his or her goals and the organization's goals in personal terms.

Commitment is an important factor and has received a significant worth in studies being carried on in different work settings, because it has been considered as a major factor in determining the organizational performance (Beer et al. 1984, Armstrong and Murlis, 2007, Ricketta 2002) and effectiveness (Deeprose, 1994, Laschinger 2001, Taing, et al. 2011,). Despite these numbers of studies, little empirical studies exist on pay structures and its effect on continuance commitment in developing countries especially in Nigeria. To bridge this gap, this study examines the effect of pay structures on continuance commitment. By exploring the relationship between pay structures and continuance commitment, organizations can enhance their competitive advantage and effectiveness.

\section{II. literature review}

Pay is a powerful Human resource management tool for recruitment, retention, motivation and reward for work done (Amah, 2010). It is a factor that must be considered if an organization wants to remain competitive in its industry. As the demand of employers on employees have increased over the years, so the demand of employees from their employers has also become complex. What employees expect of their employers is no longer just "a fair day's pay for a fair day's work" but rather a competitive remuneration package with new innovative methods of providing benefits. Pay provides employees with a tangible reward for their services to the organization. It also provides them with a source of livelihood. Wage and salary programmes are vital to both organizations and employees for several reasons. 


\section{Pay Structure}

A company's pay structure is the method of administering its pay philosophy. The two leading types of pay structures are the internal equity method, which uses a tightly constructed grid to ensure that each job is compensated according to the jobs above and below it in a hierarchy, and market pricing, where each job in an organization is tied to the prevailing market rate.

Pay structure is often defined as the range of pay rates that are provided for the various types of jobs, skills and/or performance in one organization (Blau \& Kahn, 2003; Milkovich \& Newman, 2008). Pay structure policies consist of three major characteristics: the number of levels, differentials and criteria (Lazear \& Rosen, 1981; Milkovich \& Newman, 2008).

A company's pay structure is also defined as the method of administering its pay philosophy. The two leading types of pay structures are the internal equity method, which uses a tightly constructed grid to ensure that each job is compensated according to the jobs above and below it in a hierarchy, and market pricing, where each job in an organization is tied to the prevailing market rate. In a hierarchical pay distribution, pay structure policies tend to use many levels, tiers and large pay differentials (Lazear \& Rosen, 1981; Milkovich \& Newman, 2008). Pay structures are used to determine specific pay rates for particular jobs, usually based on the nature of the job, its content and requirements. A pay structure provides the framework within which the Organization places the pay rates for its various jobs or groups of jobs.

A company needs job descriptions for all its positions so that people know where they fall within the organization. A pay structure helps answer questions about who's who, what each person's role is, and why people are compensated differently. It also helps human resources personnel to fairly administer any given pay philosophy. For example, a company might want to pay everyone at market; or pay some people at market and some above it. Opportunities for incentives are also dealt with in the pay structure. For example, people with strategic roles will likely have opportunities for higher incentives. Pay structures are often used to develop flexibility and an increased knowledge of the business needs among the workforce.

Organizations are increasingly looking at ways to improve business performance. They are developing pay structures and systems which promote the acquisition of skills, increased flexibility, greater awareness of business requirements, a strong link between individual/team pay and the overall well-being of the organization. There tend to be a shift in emphasis from valuing the job towards valuing the individual. Pay structures tend to be less hierarchical, with pay systems which reward individuals according to their contribution towards individual or corporate goals. Pay structures, which by combining the results of market surveys and job evaluation, define the levels of pay in the organization.

\section{Continuance Commitment}

Continuance commitment is generally defined as willingness to remain in an organization because of personal investment in the form of nontransferable investments such as close working relationships with coworkers, retirement investments and career investments, acquired job skills which are unique to a particular organization, years of employment in a particular organization, involvement in the community in which the employer is located, and other benefits that make it too costly for one to leave and seek employment elsewhere.

Continuance commitment evolved from Becker's (1960) side-bet theory, which posits that employees maintain membership with their organization as a way to preserve accumulated side-bets (e.g., pension). This extrinsic form of commitment derives from instrumental principles that are based on compliance (O'Reilly \& Chatman, 1986). Compliance entails behaviors that are initiated and maintained in order to satisfy external constraints, such as obtaining a reward or avoiding a loss (Becker et al., 1996). Because Continuance Commitment derives primarily from external constraints (i.e., rewards and punishments delivered by one self sources), this form of commitment is not self-determined (Gagne' \& Deci, 2005). It is, however, important to note that while the perceived bond underlying employees' Continuance commitment to the other party is not self-determined (i.e., it exists as a means to other ends), the ends themselves may be intrinsically desirable (e.g., opportunities for personal growth) and valued for reasons other than compliance-based motivations.

Meyer and Allen (1997) define continuance commitment as "awareness of the costs associated with leaving the Organization". It is calculative in nature because of the individual's perception or weighing of costs and risks associated with leaving the current Organization (Meyer \& Allen, 1997). Meyer and Allen (1991) further stated that "employees whose primary link to the Organization is based on continuance commitment remain because they need to do so". This indicates the difference between continuance and affective commitment. The latter, affective commitment entails that employee's stay in the Organization is because they want to. Romzek (1990) describes continuance commitment as a transactional attachment. He argues that employees calculate their investment in the Organization based on what they put in and what they stand to gain if they remain with the organization. In addition to the fear of losing investments, individuals develop continuance commitment because of perceived lack of alternatives. Continuance commitment therefore reflects a calculation of the cost of leaving versus the benefits of staying. 
Continuance commitment (CC), involves appraisals of personal investments tied to one's current employment and the availability of employment alternatives (Meyer \& Allen, 1984). Employees with strong CC maintain their current employment because it provides them with desirable personal outcomes that they are unwilling to forego or because they perceive a lack of employment opportunities elsewhere. Continuance commitment can be regarded as an instrumental attachment to the Organization, where the individual's association with the Organization is based on an assessment of economic benefits gained (Beck \& Wilson, 2000). Organizational members develop commitment to an Organization because of the positive extrinsic rewards obtained through the effort-bargain without identifying with the Organization's goals and values.

The strength of continuance commitment, which implies the need to stay, is determined by the perceived costs of leaving the Organization (Meyer \& Allen, 1984). Best (1994) indicates that "continuance Organizational commitment will therefore be the strongest when availability of alternatives are few and the number of investments are high". This argument supports the view that when given better alternatives, employees may leave the Organization. Meyer et al (1990) also maintain that "accrued investments and poor employment alternatives tend to force individuals to maintain their line of action and are responsible for these individuals being committed because they need to".

This implies that individuals stay in the Organization, because they are lured by other accumulated investments which they could lose, such as pension plans, seniority or Organization specific skills. The need to stay is "profit" associated with continued participation, and termination of service is a "cost" associated with leaving. Tetrick (1995) support the profit notion by describing the concept continuance Organizational commitment as "an exchange framework, whereby performance and loyalty are offered in return for material benefits and rewards". Therefore, in order to retain employees who are continuance committed, the Organization needs to give more attention and recognition to those elements that boost the employee's morale to be effectively committed.

The "exchanged-based definition" (Alluto, Hrebiniak \& Alonso, 1973) holds that individuals are committed to the Organization as far as they hold their positions, irrespective of the stressful conditions they experience. However, should they be given alternative benefits, they will be willing to leave the Organization. Continuance commitment is also associated with the compliance stage of organizational commitment, where the employee is calculative with the need to stay in the Organization when evaluating the rewards (Beck \& Wilson, 2000). It centralizes around the employee accepting the influence of others mainly to benefit from them, through remuneration or promotion (O'Reilly, 1989). At this stage, attitudes and behaviours are adopted not because of shared beliefs but simply to gain specific rewards. This implies that at this stage employees stay in the Organization because of what they receive (Meyer \& Allen, 1997).

\section{Measures of Continuance Commitment}

Taing et al., (2011) supported two dimensions of continuance commitment; Economic exchanges (EE) and Few alternatives (FA).

\section{Economic Exchanges (EE)}

Economic exchanges are defined as commitment that develops when an employee perceives desirable economic exchange opportunities at their current job. (Taing et al., 2011). This type of commitment is based on the perception that the organization provides favorable economic exchanges (Shore, Tetrick, Lynch, \& Barksdale, 2006).

Investments can be either work related or non-work related, and commitment to an Organization can be developed as employees make side bets/investments which would be lost if employment to their Organization was terminated (Meyer and Allen, 1991). Rusbult and Farrel (1983) in Meyer and Allen (1991) has the same viewpoint as Meyer and Allen (1991), that commitment to an organization increases as the magnitude of employee investments within that Organization increase.

Costs associated with leaving an organization may include a wide variety of entities, some of which are measurable and others which are more intangible. Some measurable losses may be in the area areas of salary, accrued vacation, retirement investment or pension plan, health insurance, life insurance, and companysponsored items such as a vehicle or cellular telephone. Intangible losses may include transferability of skills, transferability of education, seniority, status, and job security

\section{Few Alternatives (FA)}

Few alternatives is defined as commitment that develops when an employee feels a sense of being trapped in their current position. (Taing et al., 2011).

The lack of alternatives element states that the more specific an employee's skills become to a particular organization the less likely they will leave (Scholl, 1981) 
Clugston et al. (2000) felt that employees' perceptions regarding their alternative job prospects and the cost associated with leaving their current Organization have an effect on the employees' continuous commitment. Rusbult and Farrel (1983, in Meyer and Allen, 1991: 72) also showed that commitment increased as the attractiveness of alternative job prospects decreased. Meyer and Allen (1991) and Iverson and Buttigieg (1999) in $\mathrm{Yu}$ and Egri, (2005: 336) are in agreement with the above views and they state that continuous commitment will develop as a function of a lack of alternative job opportunities.

\section{Pay Structure and Continuance Commitment}

Empirical studies about pay structure (e.g., pay gaps, pay rates and pay entitlements) have been conducted by Bloom (1999) in Indiana State University, Summer and Miller (2000) in Southeastern United States, and by Ismail, Ismail and Sulaiman (2007) in Malaysian public institutions of higher education. These studies found that pay structures distributed for similar and/or different job categories based on the distribution rules of seniority, length of service, merit and/or contribution etc. had strongly invoked employees' perceptions of distributive justice and that this feeling might thus have led to enhanced job commitment.

Compensation research literature is consistent with the findings of fundamental social comparisons based on distributive justice theories, namely Adams' (1963 \& 1965) equity theory and Allen and White's (2002) equity sensitivity theory. Adams' equity theory posited that employees expect to receive fair outcomes such as pay, bonus, benefits, security, recognition etc. for their inputs (e.g., education, effort, time, commitment and experiences) to their jobs. If their inputs are greater than the outputs, employees will feel that they are unfairly treated. They may become de-motivated and reciprocate by showing low commitment in their work (Adams, 1963 \& 1965; Sweeney \& McFarlin, 1993). Conversely if they perceive their pay as fair, this feeling may lead to an increased job commitment (Sweeney \& McFarlin, 1993). However, according to Allen and White (2002), relative preferences of individuals for fairness in the distribution of rewards also influence their job commitment. Positive perceptions of distributive justice are associated with higher levels of job commitment i.e. intention to stay etc. (Schaubroeck, May \& Brown, 1994) whereas negative perceptions of distributive justice strongly lead to low job commitment i.e. intention to search for other jobs etc. (Sagie, 2002; Stumpf \& Hartman, 1984). From the foregoing, the following hypotheses were derived.

$\mathrm{Ho}_{1}: \quad$ There is no significant relationship between pay structure and economic exchange.

$\mathrm{Ho}_{2}$ : There is no significant relationship between pay structure and few alternatives.

\section{Research Methodology}

This correlational study was conducted as a cross-sectional survey. The study units for data generation were employees in 31 registered and functional manufacturing companies in Port Harcourt and the micro-level of analysis was adopted. A sample size of 357 employees was determined using the Taro Yamen's formula (Baridam, 2001). After cleaning, 210 copies of the instrument were used for the analysis. In selecting the respondents the simple random sampling technique was adopted. - The dimensions of Pay Structure adopted for this study are based on the earlier study of Guthrie (2000) on Compensation management. A four-item scale was developed.

The dependent variable is Continuance Commitment. The measures of Continuance Commitment adopted for this study are based on the earlier study of Taing, et el (2011) and includes economic exchange and few alternatives. Economic Exchange - A six-item scale was developed based on the 12 -item multidimensional scale developed by Taing, et al 2011. Few Alternatives - A six-item scale was developed based on the 12 -item multidimensional scale developed by Taing, et al 2011. A five-point Likert type scale was used (ranging from 5 -strongly agree to 1 - strongly disagree) for all.

For test of reliability of the scale, the following Cronbach's alpha coefficients were obtained: Pay Structure (0.70), Economic Exchange (0.85), Few Alternatives (0.83). In accordance with Nunnaly (1978) model, which recommends a bench mark of 0.70 , the reliability levels of the study scale are acceptable. Spearman's Rank Correlation Statistical tool was used to test the hypothesis. The result as presented was obtained.

\section{RESEARCH RESULTS AND FINDINGS}

Frequencies and descriptives were used in our primary analysis which focused on the study demographics and univariate analysis respectively. The results show that $64 . \%$ of the respondents were males while $36 \%$ were females. $39 \%$ of the respondents have spent $0-9$ years on their jobs while $28 \%$ have spent between 10 and 20 years. $33 \%$ of the respondents have spent over 20years on their present employments. On educational qualification, we had the following distribution: 7\% High School, 5\% Diploma, 64\% HND/BSc, 5\% Masters. $6 \%$ of the respondents had stayed less than a year. $12 \%$ have stayed $1-2$ years, $21 \%$ had stayed 3-5 years, $28 \%$ had stayed 6-10 years, while $33 \%$ had stayed 10 years and above. 
HYPOTHESIS $1\left(\mathrm{HO}_{1}\right)$ : There is no significant relationship between pay structure and economic exchanges.

Table 1. Results of Spearman Correlations for items of Pay Structure and Economic Exchanges.

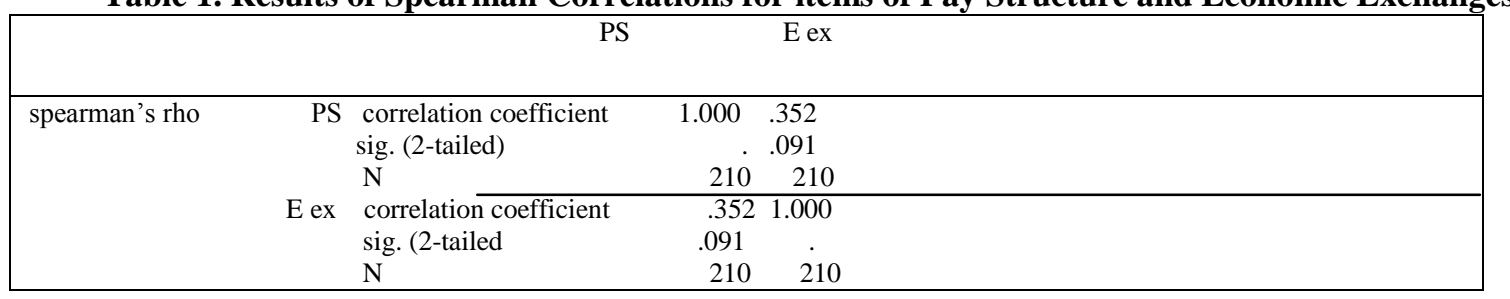

In connection with hypothesis 1 , correlation analysis was conducted with economic exchanges as the dependant variable and pay structure as the independent variable. Results show that, ( $\mathrm{rs}=0.352, \mathrm{P}<0.05)$. The test of significance indicates that with $p<0.05$ we can reject the null hypothesis that both variables are independent in the general population. This figure suggests that there is positive relationship between pay structure and economic exchanges. . In other words, increase in pay structure is associated with increase in economic exchange in the manufacturing organizations studied.

Thus, null hypothesis was rejected and alternative hypothesis accepted.

HYPOTHESIS $2\left(\mathrm{HO}_{2}\right)$ : There is no significant relationship between pay structure and few alternatives.

Table 2. Results of Spearman Correlations for items of pay structure and few alternatives

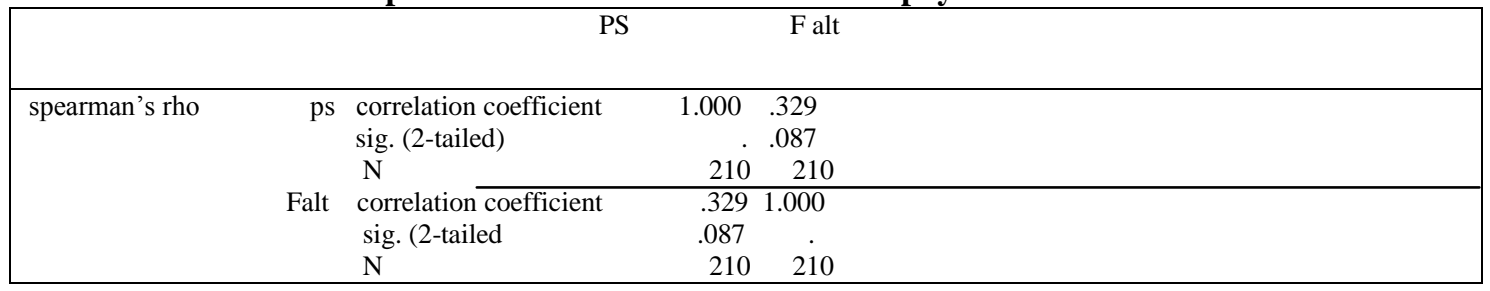

Regarding hypothesis 2, correlation analysis was conducted with few alternatives as the dependant variable and pay structure as the independent variable. Results show that, ( $\mathrm{rs}=0.329, \mathrm{P}<0.05)$. This figure suggests that there is positive relationship between pay structure and few alternatives. . In other words, increase in pay structure is associated with increase in few alternatives in the manufacturing organizations studied.

Thus, null hypothesis was rejected and alternative hypothesis accepted.

\section{Discussion And Implications}

The discussion of findings will be undertaken in relation to the hypotheses.

The first and second hypotheses sought to examine the effect of pay structure on the measures of continuance commitment, (which are economic exchanges and few alternatives) in manufacturing companies in Nigeria. The hypotheses were that there is no significant relationship between pay structures and measures of continuance commitment (economic exchanges and few alternatives). The hypotheses were tested using spearman rank correlation technique and from the analysis of collected data, a positive relationship was revealed between pay structures and measures of continuance commitment. This finding is in line with the earlier findings of, Bloom (1999) in Indiana State University, Summer and Miller (2000) in Southeastern United States, and by Ismail, Ismail and Sulaiman (2007) in Malaysian public institutions of higher education, who found that pay structures distributed for similar and/or different job categories based on the distribution rules of seniority, length of service, merit and/or contribution etc. led to enhanced commitment. This findings may be explained by the fact that in Nigeria, employees in the manufacturing companies expect to receive fair outcomes for their inputs, considering their levels of pay as investments to be lost if they left their organizations.

Employees tend to be more committed when they find out that they are not being exploited by their employers (Adam 1963,1965: Amah, 2010). Improved pay structure enhances the economic exchange which makes employee want to stay and be committed to the organization.

Continuance commitment increases with lack of attractive alternative. Due to the high rate of unemployment prevalent in the country it is difficult to find attractive alternatives. Thus employee count the cost of leaving before considering any such move, this is in accordance with what Clugston et al (2000) said that the cost associated with leaving is related to employees' continuance commitment. When the cost is high, it 
makes employees to be more committed to their organizations. The pay structure tends to be more acceptable when there are few alternatives.

Employees' investment in the organization and possible benefits at the end also makes employees want to stay and be committed.

\section{Conclusion And Recommendation}

Based on the discussions above, we conclude that the implementation of pay structures significantly enhances employees' continuance commitment (economic exchanges and few alternatives) within the Nigeria work environment and the manufacturing sector to be specific. The positive association between pay structures and continuance commitment as established by the study is applicable to work organizations the world over including African based organizations like the ones that make up our study population.

Based on the above discussions, we recommend that the manufacturing sector should focus on the factors that positively impact employee continuance commitment. Most organizations in the industry have fairly competitive compensation programmes, but could benefit if they revisit their current offering and include the essential elements of what staff would like to receive.

\section{LIMITATIONS OF THE STUDY}

The fact that this is a study of the manufacturing industry, limits the extent to which generalizations of any outcome of this study can be applied to all other sectors and industries in the Nigerian economy. The study can be carried out in other sectors of the economy. It can also be carried out in other countries.

\section{References}

[1]. Adams, J.S. (1963). Towards an understanding of inequity. Journal of Abnormal and Social Psychology, 67 (5), $422-436$

[2]. Adams, J.S. (1965). Inequity in social exchange. In Berkowitz, L. (ed.) Advances in Experimental Social Psychology. New York: Academic Press

[3]. Allen, N. J. \& Meyer, J. P. 1996. Affective, continuance and normative commitment to the organization: An examination of construct validity. Journal of Vocational Behaviour, Vol. 49: 252-276

[4]. Allen, R. S. \&White, C. S (2002) Equity Sensitivity Theory: A test of responses to two types of under- reward situations. Journal of Managerial Issues, 14, 435-451

[5]. Allutto, J. A., Hrebiniak, L. G. \& Alonso, R. C. (1973). On operationalizing the concept of commitment. Social Forces, 51, 448 454.

[6]. Amah, E. (2010) Human Resource Management. Amethyst Publishers, Port Harcourt.

[7]. Armstrong, M., \& Murlis, H. (2007). Reward management. London: Kogan Page Ltd.

[8]. Becker, H. S. (1960) Notes on the concept of commitment. The AmericanJournal ofSociology, 66(1): 32-40.

[9]. Becker, T. E., Billings, R. S., Eveleth, D. M., \& Gilbert, N.W. (1996). Foci and bases of commitment: Implications for performance. Academy of Management Journal, 39, 464-482

[10]. Beck, K. \& Wilson, C. (2000). Development of affective organizational commitment. A cross-sequential examination of change with tenure. Journal of Vocational Behaviour, 56, $114-136$.

[11]. Beer, M., Spector, B., Lawrence, P.R., Mills, D.Q., \& Walton, R.E. (1984).Managing human assets. New York: The Free Press

[12]. Best, P. W. (1994). Locus of control, personal commitment and commitment to the organisation. Unpublished M. Com thesis. University of South Africa, Pretoria.

[13]. Blau, F.D., \& Kahn, L.M. (2003). Understanding international differences in the gender pay group. American Economic Review, 21 (1), 106-145

[14]. Bloom, M. (1999) The performance effects of pay dispersion on individuals and organizations. Academy of Management Journal, 42 (1), 25-40

[15]. Clugston, M., Howell, J.P., and Dorfman, P.W. 2000. "Does cultural socialization predict multiple bases and foci of commitment?" Journal of Management, 26(1): 5 -30

[16]. Cohen, A., (1993). „Organizational Commitment and Turnover: A Meta-Analysis”, Academy of Management Journal, October 1993, pp. 1140-57;

[17]. Cohen, A. (2003). Multiple Commitments in the Workplace: An integrative Approach. London: Lawrence Erlbaum Associates Publishers.

[18]. Deeprose, D. (1994). How to recognise and reward employees. New York: Amacom.

[19]. Saal, F. E and Knight, P. A (1987). Industrial/Organizational Psychology: Science and Practice Pacific Grove: Brookes Cole.

[20]. Gagne, M., \& Deci, E. L. 2005. Self-determination theory and

[21]. work motivation. Journal of Organizational Behavior, 26: 331-362.

[22]. Ismail, A., Ismail, Y., \& Sulaiman, M. (2007). Distributive justice, pay structure, and attitudes and behavior: A case of Malaysian public institutions of higher learning. Paper presented at the

[23]. $\quad$ proceeding of Academy for Global Business Advancement, 4 (1), 619-618.

[24]. Laschinger H.K.S., Finegan J., Shamian J.\&Wilk P. (2001) Impact of structural and psychological empowerment on job strain in nursing work settings. Journal of Nursing Administration 31, 260-272.

[25]. Lazear, E., \& Rosen, S. (1981). Rank-order tournaments as optimum labour contracts. Journal of Political Economy, 89, 841-864.

[26]. Meyer, J. P., \& Allen, N. (1997). Commitment in the workplace: Theory, research, and application. California: Sage.

[27]. Meyer, J P, Allen, N J, and Gellatly, 1 R (1990). "Affective and continuance commitment to the organization: Evaluation of and analysis of concurrent and time-lagged relations", Journal of Applied Psychology, 75, pp. 710-720.

[28]. Meyer, J P and Allen, N J (1984). "Testing the side-bet theory of organizational commitment: Some methodological considerations", Journalof Applied Psychology, 69, pp. 372-378.

[29]. Meyer, J. P. \& Allen, N. J. 1991. A three component conceptualization of organizational commitment. Human Resource Management Review, Vol. 1: 61- 89

[30]. Milkovich, G.T., \& Newman, J.M. (2008). Compensation Boston: Irwin McGraw Hill. 
[31]. O'Reilly, C. A., III, \& Chatman, J. 1986. Organizational commitment and psychological attachment: The effects of compliance, identification, and internalization on prosocial

[32]. behavior. Journal of Applied Psychology, 71: 492- 499.

[33]. O'Reilly, C. 1989. "Corporations, culture, and commitment: Motivation and social control in organisations". California Management Review, 31(4): 9 - 25

[34]. Riketta, M. (2002). Attitudinal organizational commitment and job performance: A meta-analysis. Journal of Organizational Behavior, 23.

[35]. Romzek, B. S (1990) Employee Investment and Commitment. The Ties that Bind. Public Admin Review 50, $374-382$

[36]. Sagie, A. (2002). Employee absenteeism, organizational commitment and job Satisfaction: another look. Journal of Vocational Behavior, 52, 156-171.

[37]. Schaubroeck, J., May, D.R., \& Brown, F.W. (1994). Procedural justice explanations and employee reactions to Economic hardship: A field experiment. Journal of Applied Psychology, 79, 455-60.

[38]. Scholl, R. W. (1981). Differentiating organizational commitment from expectancy as a motivating force. Academy of Management Review, 6(4): 589-599.

[39]. Shore, L.M., Tetrick, L.E., Lynch, P., \& Barksdale, K. (2006). Social and economic exchange: Construct development and validation. Journal of Applied Social Psychology, 36, 837-867.

[40]. Stumpf, S.A. \& Hartman, K. (1984). Individual exploration to organizational commitment or withdrawal. Academy of Management Journal, 27, 308-329.

[41]. Summer, T.P., \& Miller, J.L. (2000). Intra-and inter-justice relationships: Assessing the direction. Human Relations, 53 (10), 329 1347.

[42]. Sweeney, P.D., \& McFarlin, D.B. (1993). Workers' evaluation of the 'ends' and the 'means': An examination of four models of distributive and procedural justice. Organizational Behavior $\quad$ and Human Decision Processes, 55, 23-49.

[43]. Taing, M. U., Groff, K. W., Granger, B. P., Jackson, E. M., \& Johnson, R. E. (2011). The multidimensional nature of continuance commitment: Commitment owing to economic exchanges versus lack of employment alternatives. Journal of Business and Psychology, 26.

[44]. Tetrick, L.E. (1995). Developing and maintaining union commitment: A theoretical framework. Journal of Organizational Behavior, 16 (Special Issue: Union Commitment), 583-595.

[45]. Yu, B.B., and Egri, C.P. 2005. "Human resource management practices and affective organizational commitment: A comparison of Chinese employees in a state-owned enterprise and a joint venture". Asia Pacific Journal of HumanResources, 43(3):332- 60 